\title{
Marshall R. Urist and the discovery of bone morphogenetic proteins
}

\author{
Lovorka Grgurevic $^{1} \cdot$ Marko Pecina $^{2} \cdot$ Slobodan Vukicevic ${ }^{1}$
}

Received: 29 December 2016 / Accepted: 3 January 2017 / Published online: 11 February 2017

(C) The Author(s) 2017. This article is published with open access at Springerlink.com

\begin{abstract}
Over the last 40 years International Orthopaedics has published a series of articles on bone morphogenetic proteins (BMPs) covering topics from basic research to clinical applications. This includes also work submitted from the Laboratory for Mineralized Tissues of the School of Medicine University of Zagreb. Accordingly, we felt obliged to give a short summary of Dr. Urist's life and work as our gratitude to his discovery that demineralized bone matrix (DBM) activity induces bone when implanted ectopically into the muscle or under the skin due to bone inducing proteins, named BMPs.
\end{abstract}

Keywords Marshall Urist · Bone morphogenetic proteins · Heterotopic ossification $\cdot$ Bone regeneration

Dr. Marshall R. Urist was born in Chicago on June 11, 1914 and grew up on a small farm in South Haven, Michigan. He received his undergraduate degree in chemistry from the University of Michigan and, after earning a master's degree at the University of Chicago, entered the Johns Hopkins University School of Medicine, receiving his medical degree in 1941. He completed his surgical residency at Johns Hopkins and at Massachusetts General Hospital (MGH). Urist joined the war in 1943 as Chief of Orthopaedics in the

Lovorka Grgurevic

lgrgurev@mef.hr

1 Laboratory for Mineralized Tissues, Center for Translational and Clinical Research, School of Medicine, University of Zagreb, Salata 11, 10000 Zagreb, Croatia

2 Department of Orthopaedic Surgery, School of Medicine, University of Zagreb, Salata 11, 10000 Zagreb, Croatia 22nd General Hospital Division in England, and the 97th General Hospital Division in Germany. After resigning from the military, he became a senior resident at MGH and completed his training with a fellowship in orthopaedic surgery at Children's Hospital in Boston, where he worked on the management of poliomyelitis. In 1947, he moved to Chicago to resume his collaboration with Franklin McLean at the Department of Physiology and Research. His experiments focused on osteoporosis and hormone regulation of bone homeostasis [2]. In 1948, he joined the faculty of the new School of Medicine at the University of California at Los Angeles as an Assistant Professor of Surgery. He was promoted to Associate Professor in 1954 and to Professor of Surgery, Orthopaedics in 1969. He died at his home on February 4, 2001, in Los Angeles [4].

Dr. Urist's areas of interest include bone and joint biology, bone morphogenetic proteins, calcium metabolism, bone grafts, oestrogens and bone metabolism. He contributed to the discipline of orthopaedic surgery in many ways but the main contribution was his interest in basic research [23]. With grants from a private foundation, he set up the Bone Research Laboratory in Wilshire.

Bone regeneration was the main concern of Dr. Urist since his graduation when he read the book by Leriche and Policard where authors mentioned "the juice of stonemaking" which generates bone in muscle [2]. The phenomenon of heterotopic bone formation was best described in experiments performed by Charles Huggins (1929-1931) on the uroepithelial tissue in dogs. Huggins was awarded the 1966 Nobel Prize for Physiology or Medicine for his discovery that hormones could be used to control the spread of some cancers. This was the first discovery that cancer could be controlled by chemicals $[14,15]$.

In 1965, Dr. Urist showed that new bone formation could be induced by DBM implanted under the skin or into the 
muscle of animals [29]. With these studies, Dr. Urist pioneered the concept of substance naturally present in bone, responsible for the regeneration and bone repair activity. $\mathrm{He}$ called this substance the bone inductive principle BMP, bone morphogenetic protein, introducing the new term to describe the nature of this bone inductive factor and initiated a search for these molecules [30]. He spent the next three decades isolating and purifying BMP molecules. Throughout the 1970s, pre-clinical research in Dr. Urist's laboratory demonstrated the involvement of BMP in the bone formation cascade of mitosis, chemotaxis, differentiation, callus and bone formation (endochondral and intramembranous). The advances in molecular biology in the 1980s and early 1990s allowed the sequencing and cloning of BMPs. Cloned for the first time in 1988 by a research team at the Genetics Institute led by Dr. John Wozney, BMP proved to be a member of the TGF-beta superfamily of cytokines [40]. The first publications on the clinical use of BMP in non-unions and segmental bone defects began in the late 1980s by Johnson et al. [16] in tibial defects. Dr. Urist's work resulted in the publication of over 400 papers and the presentations of more than 200 lectures throughout the world. Availability of rhBMPs permitted the large scale evaluation of their efficacy and safety in a large number of animal models, thus allowing for optimization of both carrier and dose of BMPs for clinical use $[6,8-11,13,17,19,21,22$, 24, 27, 38].

Native BMPs were tested in clinical trials under Dr. Urist's supervision at the University of California at Los Angeles (UCLA) where patients with difficult non-unions and bone defects were successfully treated.

We had an opportunity to personally interact (Fig. 1) and exchange ideas regarding heterotopic ossification with Dr. Urist. The first contact was established in 1983 when Prof. Vukicevic contacted Dr. Urist regarding the discovery of heterotopic ossification in the anterior abdominal wall of a cadaver found during an anatomical dissection, a case report published in Plastic and Reconstructive Surgery [39]. The

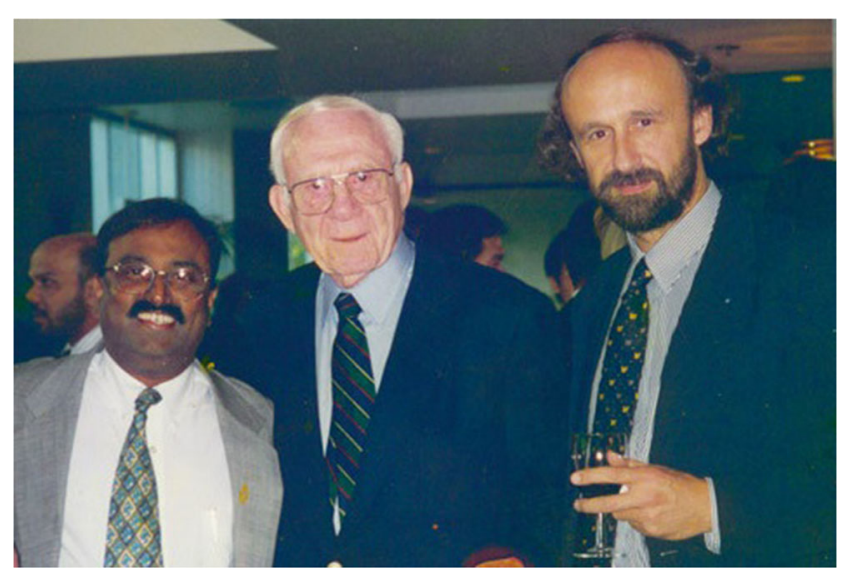

Fig. 1 Second International BMP Conference Sacramento 1997. From the left to right: Kuber Sampath, Marshall Urist and Slobodan Vukicevic paper reported on a membranous bone transplant found in the anterior abdominal wall of an 82-year-old man. Histological and bone mineral content analyses revealed that bone graft underwent little bone resorption and induced new bone formation and that it represented a parietal skull bone removed following benign brain tumor surgery and implanted into the abdominal wall for a delayed skull closure [39]. Dr. Urist kindly replied to the letter, gave useful advice and shared some of his experience associated with heterotopic ossification. In the letter Dr. Urist mentioned that he was working with bone morphogenetic proteins (Fig. 2), which in time became the main research interest of Professor Vukicevic and his scientific team as well as many international collaborators.

Dr. Vukicevic and Dr. Pecina explored the mechanisms and function of BMPs in patients with non-unions $[3,7,20,21,26$, 31-33, 37], and Dr. Grgurevic made important contributions to understanding the role of circulating BMPs that led to the use of BMP6 locally in patients with bone defects $[1,26$, 32-34]. With numerous collaborators they published important discoveries and organized international BMP conferences (Figs. 3 and 4).

Dr. Urist was a distinguished leader and his contributions as a scientist, surgeon, clinician, writer and editor are legendary. He trained and mentored hundreds of young medical residents, fellows and researchers, and his bone laboratory became a centre of scientific and intellectual exchange. Dr. Urist won numerous academic honours, including two kappa Delta awards for his work on oestrogen effects on bone and work on BMPs. The First International Conference on BMP was also held at Johns Hopkins University in 1994 to honour Dr. Urist. In 1991, professor Ian Goldie nominated Dr. Urist for the Nobel Prize in Physiology or Medicine which was based on his early work on bone physiology and the discovery of bone formation, BMPs and his clinical research in orthopaedics.

The research area of BMPs has significantly expanded in the past two decades and covered many areas but has primarily remained in the field of bone regeneration. The foundation that Dr. Urist set by the discovery of BMPs provided a good basis for further preclinical research and development of new bone regeneration products by taking advantage of the basic characteristics of BMPs as a potent bone-forming agent in vivo, with the ability of restoring bone loss in postnatal life by recapitulation of events that are similar to those in the embryonic development. BMPs are members of the TGF beta superfamily and have diverse roles in development, repair and regeneration [34-37]. BMP2 and BMP7 have been most studied in the context of bone healing [5, 9, 28]. Two therapeutic concepts have been introduced to the market to overcome bone non-healing or complicated bone fractures consisting

Fig. 2 Marshall Urist's letter to Slobodan Vukicevic. It relates to the discovery of a large ectopic bone in the anterior abdominal wall of a cadaver 
UNIVERSITY OF CALIFORNIA, LOS ANGELES

BERKELEY - DAVIS - IRVINE - LOS ANGELES - RIVERSIDE - SAN DIEGO - SAN FRANCISCO

April 14, 1983

Professor Slobodan Vukicevic, M.D.

Zavod Za Anatomiju

Drago Perovic

Medicinskog Fakulteta Sveucilista U Zagrebu

41001 Zagreb, Salata 11

P.P. 286
U.C.L.A. BONE RESEARCH LABORATORY

REHABILITATION CENTER

1000 VETERAN AVENUE

LOS ANGELES, CALIFORNIA 90024

Dear Professor Vukicevic:

Thank you for the most interesting letter and specimen of heterotopic bone in the anterior abdominal wall of an 82 year old man.

The most commonly described deposits of heterotopic bone in the anterior abdominal wall are in mid-line incisions, just below the xiphoid process of the sternum. The heterotopic bone you described has a unique shape and is larger in volume than anything previously described in the literature on the anterior abdominal wall.

If I were an anatomist or a pathologist, I would have a portable $x$-ray machine in the autopsy room and $x$-ray the entire skeleton. In the days before $x$-ray, Rudolph Virchow would have his diener excise and re-articulate the entire skeleton for him to examine. In our times, the same purpose could be accomplished by a total $x$-ray skeletal survey. I predict you would find all kinds of pathological lesions that were unappreciated in the life time of the individual. For example in your cadaver, it would be interesting to know whether the man had had any other bone disease anywhere else in his body. For example, the intertransverse processes are predisposed to ossification and spontaneously ossify in paraplegics. Men with severe osteoarthritis appear to be more susceptible to heterotopic bone deposits then normal individuals. As you know, I am working on a bone morphogenetic protein (BMP) and we are now doing BMP radioimmunoassays to identify patients in populations at risk for heterotopic bone formation.

I agree with you that your specimen is not likely to be an ossifying hematoma. There is no evidence that hematomas ever ossify. There are cases in the literature of very old unabsorbed hematomas with calcification in the fibrous tissue envelope of the hematoma and that is where heterotopic ossification may occur many years after injury-related hematomas.

I am returning, herewith, the photographs and the negatives which are valuable and should be used for preparation of a case report.

I realize that it is difficult to do a retrospective study on a cadaver specimen, even though the medical history is available. Negative information is of limited value.

For research on your specimen, I would carefully remove a long wedge-shaped segment of the specimen, covering its radius in the long dimension and cut a cross-section histological and histochemical studies. I would look a parasitic infestation in the marrow cavity of the specimen and depending upon what the routine histological sections show, I would perform a battery of histochemical stains. The unique size, shape and location would seem to justify a brief report to the literature on heterotopic bone. Rebel of France has found virus bodies in EM of osteoclasts in patients with Pagets Disease. Wlodarski of Warsaw Academy in Poland has produced heterotopic bone in mice injected with vaccinia transformed fibroblasts.

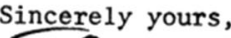

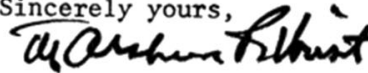

Marsha11 R. Urist, M.D.

Professor of Surgery

(Orthopedics)

MRU: p1 


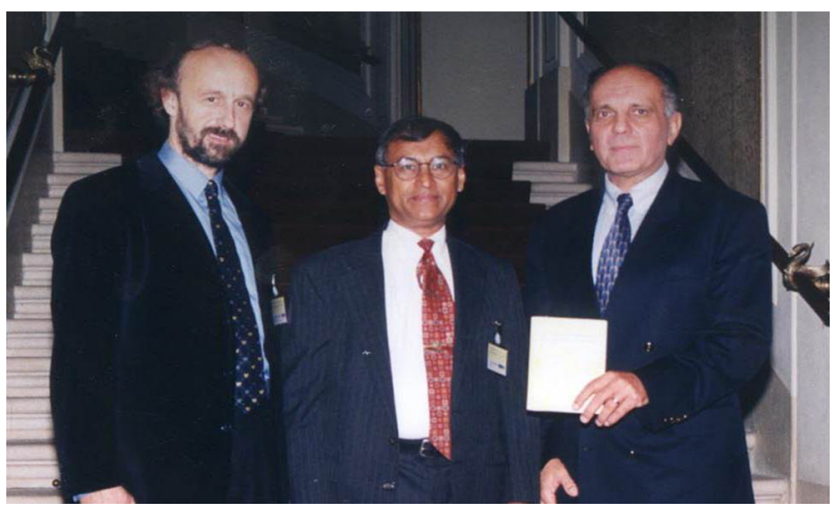

Fig. 3 First European BMP Conference 1998 in Zagreb. From left to right: Slobodan Vukicevic, Hari Reddi and Marko Pecina in the Croatian National Theatre

of bovine collagen as a carrier which is soaked with BMP2 (Infuse Bone Graft) or BMP7 (Osigraft) [8, 18, 33]. BMP2 has received approval for several clinical indications (open tibial shaft fractures and anterior fusion of the lumbar spine in patients with degenerative disc disease [DDD]). Due to serious side effects of BMP2 $[12,25]$ there is still a need to develop safer and more effective therapies for bone regeneration. In order to avoid the occurrence of side effects and limitations which include ectopic ossification outside the bone compartment, oedema, inflammation, bovine collagen as a BMP carrier, and a high product price, new therapeutic concepts are being developed and tested in a large number of preclinical animal models. OSTEOGROW is a new bone device consisting of BMP6 and a biocompatible blood coagulumderived carrier currently tested in Phase I/II clinical testing in patients with high tibial osteotomy (HTO) and distal radius fracture (DRF) in three European countries. The first safety report after completion of Phase II in patients with HTO indicate that no serious side effects have been reported [33, 34].

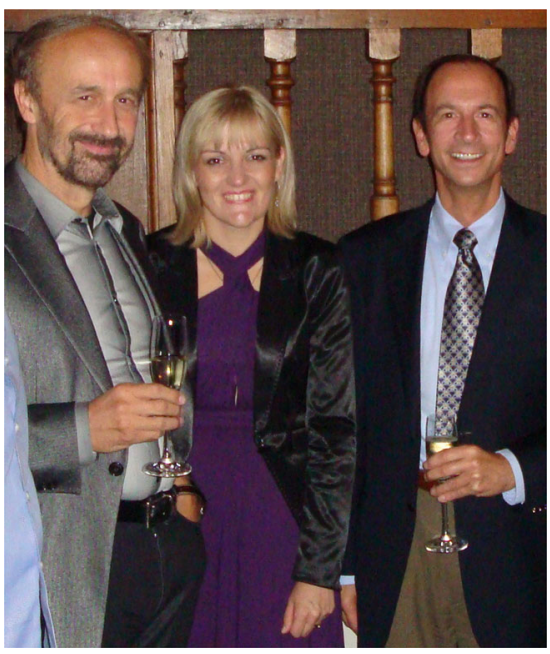

Fig. 4 8th International Conference on BMPs 2010 in Leuven, Belgium. From left to right: Slobodan Vukicevic, Lovorka Grgurevic and John Wozney
The existence of a link between the founder and those who learn from him proved to be in accordance with the metaphor: standing on the shoulders of giants (Latin: nanos gigantum humeris insidentes) expressing the meaning of "discovering truth by building on previous discoveries". The concept has been traced to the 12th century, attributed to Bernard of Chartres [11]. The future of BMPs as regulators of almost all developmental and postnatal events provides a platform for future discoveries on segmental bone healing and systemic bone biology [34].

\section{Compliance with ethical standards}

Conflict of interest MP declares no conflict of interest. LG is employed by the School of Medicine, University of Zagreb and is actively involved in the development and clinical testing of Osteogrow, a new BMP6 therapeutic implant for bone regeneration. SV is employed by the School of Medicine, University of Zagreb and is the founder of Genera Research, a Croatian biotechnology company conducting clinical trials with Osteogrow.

The Osteogrow program is funded by the EU Commission for science (FP7 Health, Grant agreement no: 279239).

Open Access This article is distributed under the terms of the Creative Commons Attribution 4.0 International License (http:// creativecommons.org/licenses/by/4.0/), which permits unrestricted use, distribution, and reproduction in any medium, provided you give appropriate credit to the original author(s) and the source, provide a link to the Creative Commons license, and indicate if changes were made.

\section{References}

1. Andriopoulos B Jr, Corradini E, Xia Y, Faasse SA, Chen S, Grgurevic L, Knutson MD, Pietrangelo A, Vukicevic S, Lin HY, Babitt JL (2009) BMP-6 is a key endogenous regulator of hepcidin expression and iron metabolism. Nat Genet 41:482-487. doi:10.1038/ng. 335

2. Bauer H, Nilsson O (2001) Marshall Raymond Urist: 1914-2001. Acta Orthop Scand 72:318-319. doi:10.1080/00016470152846691

3. Bilic R, Simic P, Jelic M, Stern-Padovan R, Dodig D, Pompe H, Martinovic S, Ivankovic D, Pecina M, Vukicevic S (2006) Osteogenic protein-1 (BMP-7) accelerates healing of scaphoid non-union with proximal pole sclerosis. Int Orthop 30:128-134. doi:10.1007/s00264-005-0045-z

4. Brand RA (2009) Marshall R. Urist, 1914-2001. Clin Orthop 467: 3049-6050. doi:10.1007/s11999-009-1067-4

5. Buza JA III, Einhorn T (2016) Bone healing in 2016. Clin Cases Min Bone Metab 13:101-105. doi:10.11138/ccmbm/2016.13.2.101

6. Courvoisier A, Sailhan F, Laffenêtre O, Obert L, French Study Group of BMP in Orthopedic Surgery (2014) Bone morphogenetic protein and orthopaedic surgery: can we legitimate its off-label use? Int Orthop 38:2601-2605. doi:10.1007/s00264-014-2534-4

7. Das SP, Ganesh S, Pradhan S, Singh D, Mohanty RN (2014) Effectiveness of recombinant human bone morphogenetic protein7 in the management of congenital pseudoarthrosis of the tibia: a randomised controlled trial. Int Orthop 38:1987-1992. doi:10.1007 /s00264-014-2361-7

8. Dumic-Cule I, Brkljacic J, Rogic D, Bordukalo Niksic T, Tikvica Luetic A, Draca N, Kufner V, Trkulja V, Grgurevic L, Vukicevic S 
(2014) Systemically available bone morphogenetic protein two and seven affect bone metabolism. Int Orthop 38:1979-1985. doi:10.1007/s00264-014-2425-8

9. Dumic-Cule I, Pecina M, Jelic M, Jankolija M, Popek I, Grgurevic L, Vukicevic S (2015) Biological aspects of segmental bone defects management. Int Orthop 39:1005-1011. doi:10.1007/s00264-015$2728-4$

10. Fassbender M, Minkwitz S, Thiele M, Wildemann B (2014) Efficacy of two different demineralised bone matrix grafts to promote bone healing in a critical-size-defect: a radiological, histological and histomorphometric study in rat femurs. Int Orthop 38: 1963-1969. doi:10.1007/s00264-014-2321-2

11. Flouzat-Lachaniette $\mathrm{CH}$, Ghazanfari A, Bouthors C, Poignard A, Hernigou P, Allain J (2014) Bone union rate with recombinant human bone morphogenic protein-2 versus autologous iliac bone in PEEK cages for anterior lumbar interbody fusion. Int Orthop 38: 2001-2007. doi:10.1007/s00264-014-2301-6

12. Fu R, Selph S, McDonagh M, Peterson K, Tiwari A, Chou R, Helfand M (2013) Effectiveness and harms of recombinant human bone morphogenetic protein-2 in spine fusion: a systematic review and meta-analysis. Ann Intern Med 158:890-902. doi:10.7326 /0003-4819-158-12-201306180-00006

13. Hinsenkamp M, Collard JF (2015) Growth factors in orthopaedic surgery: demineralized bone matrix versus recombinant bone morphogenetic proteins. Int Orthop 39:137-147. doi:10.1007/s00264-014-2562-0

14. Huggins C (1967) Endocrine-induced regression of cancers. Science 156:1050-1054

15. Huggins C (1967) Endocrine-induced regression of cancers. Cancer Res 27:1925-1930

16. Johnson EE, Urist MR, Finerman GA (1988) Bone morphogenetic protein augmentation grafting of resistant femoral nonunions: a preliminary report. Clin Orthop 230:257-265

17. Kaipel M, Schützenberger S, Hofmann AT, Ferguson J, Nau T, Redl $\mathrm{H}$, Feichtinger GA (2014) Evaluation of fibrin-based gene-activated matrices for BMP2/7 plasmid codelivery in a rat nonunion model. Int Orthop 38:2607-2613. doi:10.1007/s00264-014-2499-3

18. Keith B, Vitasek K, Manrodt K, Kling K (2016) Strategic sourcing in the new economy. Palgrave Macmillan US

19. Pauk M, Grgurevic L, Brkljacic J, Kufner V, Bordukalo-Niksic T, Grabusic K, Razdorov G, Rogic D, Zuvic M, Oppermann H, Babitt JL, Lin HY, Volarevic S, Vukicevic S (2015) Exogenous BMP7 corrects plasma iron overload and bone loss in Bmp6-/- mice. Int Orthop 39:161-172. doi:10.1007/s00264-014-2550-4

20. Pecina M, Giltaj LR, Vukicevic S (2001) Orthopaedic applications of osteogenic protein-1 (BMP-7). Int Orthop 25:203-208. doi: $10.1007 / \mathrm{s} 002640100262$

21. Pecina M, Haspl M, Jelic M, Vukicevic S (2003) Repair of a resistant tibial non-union with a recombinant BMP-7. Int Orthop 27: 320-321. doi:10.1007/s00264-003-0475-4

22. Pecina M, Jelic M, Martinovic S, Haspl M, Vukicevic S (2002) Articular cartilage repair: the role of bone morphogenetic proteins. Int Orthop 26:131-136. doi:10.1007/s00264-002-0338-4

23. Reddi AH (2003) Marshall R. Urist: a renaissance scientist and orthopaedic surgeon. J Bone Joint Surg Am 85:3

24. Schwarting T, Benölken M, Ruchholtz S, Frink M, Lechler P (2015) Bone morphogenetic protein-7 enhances bone-tendon integration in a murine in vitro co-culture model. Int Orthop 39:799805. doi:10.1007/s00264-015-2688-8
25. Simmonds MC, Brown JV, Heirs MK, Higgins JP, Mannion RJ, Rodgers MA, Stewart LA (2013) Safety and effectiveness of recombinant human bone morphogenetic protein-2 for spinal fusion: a meta-analysis of individual-participant data. Ann Intern Med 158: 877-889

26. Song K, Krause C, Shi S, Patterson M, Sutto R, Grgurevic L, Vukicevic S, van Dinther M, Falb D, ten Dijke P, Alaoui-Ismaili MH (2010) Identification of a key residue mediating bone morphogenetic protein (BMP)-6 resistance to noggin inhibition allows for engineered BMPs with superior-agonist activity. J Biol Chem 285: 12169-12180. doi:10.1074/jbc.M109.087197

27. Takigami J, Hashimoto Y, Yamasaki S, Terai S, Nakamura H (2015) Direct bone-to-bone integration between recombinant human bone morphogenetic protein-2-injected tendon graft and tunnel wall in an anterior cruciate ligament reconstruction model. Int Orthop 39: 1441-1447. doi:10.1007/s00264-015-2774-y

28. Tsuji K, Bandyopadhyay A, Harfe BD, Cox K, Kakar S, Gerstenfeld L, Einhorn T, Tabin CJ, Rosen V (2006) BMP2 activity, although dispensable for bone formation, is required for the initiation of fracture healing. Nat Genet 38:1424-1429

29. Urist MR (1965) Bone: formation by autoinduction. Science 150: 893-899

30. Urist MR, Strates BS (1971) Bone morphogenetic protein. J Dent Res 50:1392-1404

31. von Rüden C, Morgenstern M, Friederichs J, Augat P, Hackl S, Woltmann A, Bühren V, Hierholzer C (2016) Comparative study suggests that human bone morphogenetic proteins have no influence on the outcome of operative treatment of aseptic clavicle nonunions. Int Orthop 40:2339-2345. doi:10.1007/s00264-016-3262-8

32. Vukicevic S, Grgurevic L (2009) BMP-6 and mesenchymal stem cell differentiation. Cytokine Growth Factor Rev 20:441-448. doi:10.1016/j.cytogfr.2009.10.020

33. Vukicevic S, Oppermann H, Verbanac D, Jankolija M, Popek I, Curak J, Brkljacic J, Pauk M, Erjavec I, Francetic I, Dumic-Cule I, Jelic M, Durdevic D, Vlahovic T, Novak R, Kufner V, Bordukalo Niksic T, Kozlovic M, Banic Tomisic Z, Bubic-Spoljar J, Bastalic I, Vikic-Topic S, Peric M, Pecina M, Grgurevic L (2014) The clinical use of bone morphogenetic proteins revisited: a novel biocompatible carrier device OSTEOGROW for bone healing. Int Orthop 38: 635-647. doi:10.1007/s00264-013-2201-1

34. Vukicevic S, Sampath TK (eds) (2002) Bone morphogenetic proteins: from laboratory to clinical practice. Birkhäuser Verlag, Basel

35. Vukicevic S, Sampath KT (eds) (2004) Bone morphogenetic proteins: regeneration of bone and beyond. Birkhäuser Verlag, Basel

36. Vukicevic S, Sampath TK (eds) (2008) Bone morphogenetic proteins: from local to systemic therapeutics. Birkhäuser Verlag, Basel

37. Vukicevic S, Sampath KT (eds) (2017) Bone morphogenetic proteins: systems biology regulators. Springer International Publishing AG. doi:10.1007/978-3-319-47507-3

38. Vukicevic S, Stavljenic A, Pecina M (1995) Discovery and clinical applications of bone morphogenetic proteins. Eur J Clin Chem Clin Biochem 33(10):661-671

39. Vukicevic S, Marusic A, Stavljenic A, Vinter I, Rudez V (1989) New bone formation in the autologous membranous bone transplanted into anterior abdominal wall. Plast Reconstr Surg 83: 889-891

40. Wozney JM, Rosen V, Celeste AJ, Mitsock LM, Whitters MJ, Kriz RW, Hewick RM, Wang EA (1988) Novel regulators of bone formation: molecular clones and activities. Science 242:1528-1534 